\title{
Ethical and Legal Issues in Modern Surgery
}




\section{Introductory Series in Medicine}

ISSN: 2045-0346

Series Editor: Nadey Hakim (Imperial College Healthcare NHS Trust, UK)

\section{Published}

Vol. 1: Clinical Intensive Care Medicine edited by Carlos M. H. Gómez

Vol. 2: Ethical and Legal Issues in Modern Surgery edited by Nadey Hakim, Vassilios Papalois \& Miran Epstein

\section{Forthcoming}

Vol. 3: Vascular Access

edited by Nadey Hakim \& Paul Herbert 


\section{Ethical and Legal Issues in Modern Surgery}

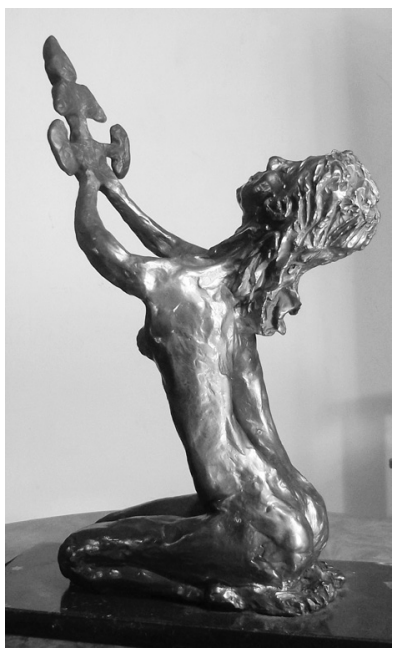

Editors

Nadey Hakim

Imperial College Healthcare NHS Trust, UK

\section{Vassilios Papalois}

Imperial College Healthcare NHS Trust, UK

\section{Miran Epstein}

Queen Mary University of London, UK 


\section{Published by}

Imperial College Press

57 Shelton Street

Covent Garden

London WC2H 9HE

\section{Distributed by}

World Scientific Publishing Co. Pte. Ltd.

5 Toh Tuck Link, Singapore 596224

USA office: 27 Warren Street, Suite 401-402, Hackensack, NJ 07601

UK office: 57 Shelton Street, Covent Garden, London WC2H 9HE

\section{Library of Congress Cataloging-in-Publication Data}

Ethical and legal issues in modern surgery / edited by Nadey Hakim, Vassilios Papalois \& Miran Epstein.

p. ; cm. -- (Introductory series in medicine ; vol. 2)

Includes index.

ISBN 978-1-84816-246-4 (hardcover : alk. paper) -- ISBN 978-1-84816-296-9 (electronic)

I. Hakim, Nadey S., 1958- ， editor. II. Papalois, Vassilios E., editor. III. Epstein, Miran, editor. IV. Series: Introductory series in medicine; v. 2.

[DNLM: 1. Ethics, Medical. 2. General Surgery--ethics. 3. General Surgery--legislation \& jurisprudence. WO 21]

RD27.7

174.2'97--dc23

2014044355

\section{British Library Cataloguing-in-Publication Data}

A catalogue record for this book is available from the British Library.

Front cover: Homage to the Organ Donor, a bronze sculpture by Sir Roy Calne, 1995

Copyright $(\mathcal{C} 2015$ by Imperial College Press

All rights reserved. This book, or parts thereof, may not be reproduced in any form or by any means, electronic or mechanical, including photocopying, recording or any information storage and retrieval system now known or to be invented, without written permission from the Publisher.

For photocopying of material in this volume, please pay a copying fee through the Copyright Clearance Center, Inc., 222 Rosewood Drive, Danvers, MA 01923, USA. In this case permission to photocopy is not required from the publisher.

Typeset by Stallion Press

Email: enquiries@stallionpress.com

Printed in Singapore 


\section{Contents}

Preface $\quad$ xi

List of Authors xiii

$\begin{array}{lll}\text { Part } 1 \text { General } & 1\end{array}$

1 Ethical Issues in Surgery: The Patient's Perspective 3 Amanda Venters

1.1 The Nature of the Relationship between Patient and Surgeon 3

1.2 Patient Autonomy 4

1.3 Informed Consent, a Process not a Signature 6

1.4 Where the Patient Lacks Competence 8

1.5 The Treatment Roadmap 11

1.6 When Things go Wrong 17

1.7 Elective Surgery and Ethics 19

$\begin{array}{ll}1.8 \text { Summary } 20 & 20\end{array}$

2 Consent for Clinical Interventions and Medical Research 23 Miran Epstein

2.1 The Traditional Doctor-Patient Relationship and its Ethics

2.2 The Contractual Relationship and the Doctrine of Informed Consent 24

2.3 Informed Consent: General Considerations 28 
2.4 Informed Consent: Criteria of Eligibility 30

2.5 The Tests 31

2.6 Who Can Give Consent and Refusal? 35

2.7 Advance Directives 36

2.8 Assent and Dissent 37

2.9 Justifications for Informed Consent 37

2.10 The Official History of Informed Consent 38

2.11 Problems of Historiography 39

2.12 Informed Consent Revisited 40

References 44

Additional Reading $\quad 45$

3 Ethical Issues in Medical Confidentiality and Privacy 47 Philip Hébert

3.1 Confidentiality 48

3.2 Privacy 52

3.3 Secrets $\quad 58$

3.4 Limits to Confidentiality 62

3.5 Grounds for Mandatory or Allowable Disclosure 65

$\begin{array}{ll}3.6 \text { Conclusions } & 70\end{array}$

$\begin{array}{ll}\text { References } & 70\end{array}$

4 Resource Allocation in Healthcare $\quad 75$

Ariel Zosmer

4.1 Introduction $\quad 75$

4.2 The Distribution of Healthcare Resources 78

4.3 Ethical Considerations of Resource Allocation 80

4.4 Legal Aspects of Resource Allocation, with Special
Reference to the UK

4.5 Conclusion 91

References 91

5 Ethical and Legal Issues in Clinical Research 95 Andrew J. T. George

5.1 Introduction 
5.2 Why Do We Need RECs? 97

5.3 What is the Mechanism for Ethical Review? 99

5.4 What are the Ethical Factors that RECs Look at? 103

5.5 What "Tools" Do RECs Use in Considering

Ethical Issues? 108

5.6 Does REC Scrutiny Ensure Ethical Research? 111

5.7 Conclusions 113

Acknowledgements 113

$\begin{array}{ll}\text { References } & 113\end{array}$

6 Medical Negligence and Malpractice 115

Bernard M. Dickens

6.1 Introduction 115

6.2 The Law of Negligence 116

6.3 Defences 134

6.4 Cross-Border Jurisdiction 136

6.5 Medical Malpractice 138

References 142

7 Surgical Training 143

S. R. Patel, P. Chadha and N. Hakim

7.1 Introduction

7.2 Learning through Operating 144

7.3 The European Working Time Directive (EWTD) 147

7.4 Academic Surgery 151

7.5 Surgical Training Abroad 153

$\begin{array}{ll}7.6 \text { Conclusions } & 155\end{array}$

References 156

8 Great Expectations: Towards a Greater

Understanding of Ethics in Policing

by Exploring Practices in the Medical Profession

Allyson MacVean

References 
9 Ethical and Legal Issues in Anaesthetics Jeremy Campbell and Felicity Plaat

9.1 Consent for Anaesthesia

9.2 Special Circumstances

9.3 Maternal Fetal Conflicts and the Role of the Anaesthetist

9.4 Anaesthesia for Jehovah's Witness Patients

9.5 Anaesthesia for Patients with "Do Not Attempt Resuscitation" Decisions

References

10 Neurosurgery: Ethical and Legal Issues

Howard Morgan, Louis Whitworth, Christopher Madden and Duke Samson

10.1 Ethics and the Neurosurgeon

10.2 Neurosurgeons and the Law

10.3 Stereotactic and Functional Neurosurgery

10.4 The Neuro-Revolution:

The New Neuro-Disciplines and Neurosurgery

10.5 Conclusion

References

11 Ethical and Legal Issues in Modern Cardiothoracic Surgery

Kamran Baig and Jon Anderson

11.1 Historical Perspective

11.2 Coverage of Ethical Issues in

Cardiothoracic Surgery in Literature

11.3 Principles of Ethics

11.4 Informed Consent

11.5 Coronary Revascularization: Evidence-based

Practice versus Informed Consent

11.6 Ethics of Innovation in Cardiothoracic Surgery

11.7 The Ethics of Publication of Cardiothoracic 
11.8 Withdrawing Life-sustaining Treatments 236

11.9 Ethical Issues in Heart and Lung Transplantation 238

11.10 Stem Cell and Cloning Research 247

11.11 Conclusions 248

$\begin{array}{ll}\text { References } & 249\end{array}$

12 Obstetrics and Gynaecological Surgery: The Ethics and Law of Abortion and Sterilisation

Ariel Zosmer

12.1 Introduction 255

12.2 Religion and Fertility Control 258

12.3 The Ethics of Abortion and Sterilisation 265

12.4 Legal Aspects $\quad 282$

References $\quad 290$

13 Ethical Issues in Plastic and Reconstructive Surgery 297

Ivo Pitanguy, Henrique Radwanski and Aris Sterodimas

13.1 Introduction 297

13.2 Respect for Patient Autonomy and Informed Consent 298

$\begin{array}{ll}13.3 \text { Beneficence } & 299\end{array}$

13.4 Non-maleficence $\quad 300$

13.5 The Field of Plastic and Reconstructive Surgery 300

13.6 Training of the Plastic Surgeon 302

13.7 Marketing, Media, and Plastic Surgery 302

13.8 Innovative Research and New Technologies in Plastic Surgery 303

13.9 Conclusion 303

References 304

14 Ethical Issues in Transplantation 307 Miran Epstein

14.1 The Political Economy of Transplantation 310

14.2 Two Great Solutions 316

14.3 The Ethical Discourse: Procurement of Organs 318 
14.4 The Ethical Discourse: Distribution of Organs

15 Ethical and Legal Issues in Composite Tissue Allograft (Face, Arm, and Uterus) and Microsurgery

Richard Huxtable and Alice Guilder

15.1 Introduction

15.2 Composite Tissue Allograft: Science Fact

15.3 Best Interests: Balancing Benefits and Risks

15.4 Respecting Autonomy, Consent, and Personal Identity

15.5 In the Public Interest?

15.6 Conclusion

15.7 Post-script: Science Future?

References

16 Ethical and Legal Issues in Trauma Medicine

Rebecca C. H. Brown

16.1 Introduction: Why Trauma Medicine?

16.2 Informed Consent and Capacity 380

16.3 Research Ethics in Emergency Contexts 385

16.4 Organ Donation 387

16.5 Confidentiality and Mandatory Reporting $\quad 390$

16.6 Triage 394

16.7 Concluding Remarks $\quad 398$

References $\quad 400$

Index 


\section{Preface}

Over the second half of the twentieth and, even more so, in the twenty-first century there have been indisputably some truly dramatic changes in the overall framework and content of medical practice that also have major ethical and legal dimensions.

The provision of healthcare used to be dominated by a paternalistic attitude where the doctor was the dominant figure: he made all the major clinical decisions, his judgment was never questioned, he was the one making decisions on the allocation of resources, and in a situation when something went wrong it was highly unlikely that his ability or skill would be disputed. Nowadays, the provision of healthcare is based on a complicated partnership between healthcare providers (doctors, nurses, pharmacists, and clinical scientists), patients, administrators, and, last but not least, organizations responsible for providing finance (the government with respect to NHS systems or insurance companies with respect to private healthcare systems). The development of multicultural societies and the fact that decisions regarding the provision of healthcare and assessment of its quality have to be made on the background of so many different ethnicities, religions, cultures, and languages has made matters even more complex. The puzzle becomes even "tougher" if we add to this the ever developing phenomenon of patients travelling to seek healthcare in a country different to their country of origin or residence. Furthermore, the development of new medical specialties, the interdependence of medical specialties (with most decisions being taken not at an individual but at a multidisciplinary level) as well as the rapid development of modern 
and advance treatments for very challenging patients and the introduction of new technologies in medical practice have dramatically broadened the spectrum of ethical and legal issues related to medical practice.

Modern surgery is of course no exception from the rest of medical specialties when it comes to facing complex ethical and legal issues. Even more, we believe that the challenges in surgical practice are greater than perhaps any other specialty if we consider that surgery is always at the far front of innovation, advanced intervention, and acute care. Surgeons of all ranks feel frequently overwhelmed with the complexity of the ethical and legal challenges and this can have a profound effect for their professional but also personal well-being and, even more so, can negatively affect patient care.

This book aims to address in a systematic and comprehensive way the ethical and legal challenges related to modern surgical practice. The first part deals with the more general issues that set the overall ethical-legal framework and "scene" and the second with more specific issues related to surgical subspecialties. The chapters are written by authors with immense experience and expertise in their respective fields. Chapter 14 on "Ethical Issues in Transplantation" is considered to be a classic and the author and Imperial College Press have kindly agreed to its inclusion in this book.

We are truly grateful to all authors for their truly superb work and to the editorial team of ICP for their precious commitment and support.

We hope that the book will be a helpful and supportive "companion" for surgeons (but also colleagues from all specialties) for their ethically and legally challenging practice in an ever-changing world.

Nadey Hakim, Vassilios Papalois, and Miran Epstein

London

September 2014 


\section{List of Authors}

Jon Anderson

Consultant Cardiothoracic Surgeon

Imperial College Healthcare NHS Trust

Hammersmith Hospital, London

Kamran Baig

Consultant Cardiologist

Trent Cardiac Centre, Nottingham

Rebecca C. H. Brown

Institute of Applied Health Sciences

University of Aberdeen, Aberdeen

Jeremy Campbell

Consultant Anaesthetist

Imperial College Healthcare NHS Trust

Hammersmith Hospital, London

Priyanka Chadha

Imperial College NHS Healthcare Trust, London 
Bernard Morris Dickens

Professor Emeritus of Health Law and Policy

Faculty of Law

Faculty of Medicine and Joint Centre for Bioethics

University of Toronto, Toronto

Miran Epstein

Reader in Medical Ethics

Barts and The London School of Medicine and Dentistry

Queen Mary University of London, London

Andrew J. T. George

Deputy Vice Chancellor (Education and International)

Brunel University, London

Alice Guilder

Oxford Deanery

Nadey S. Hakim

Max Thorek Professor of Surgery

Adjunct Professor of Transplantation Surgery Imperial College London Imperial College Healthcare NHS Trust, London

Philip Hébert

Professor Emeritus, Department of Family and Community Medicine

Sunnybrook Health Sciences Centre

University of Toronto, Toronto

Richard Huxtable

Professor of Medical Ethics and Law

Centre for Ethics in Medicine

School of Social and Community Medicine

University of Bristol, Bristol

Allyson MacVean

Senior Research Fellow

Bath Spa University, Bath 
Christopher Madden

Department of Neurological Surgery

University of Texas

Southwestern Medical Centre, Dallas, Texas

Howard Morgan

Department of Neurological Surgery

University of Texas

Southwestern Medical Centre, Dallas, Texas

Vassilios Papalois

Consultant Transplant and General Surgeon

Renal and Transplant Unit

Imperial College Healthcare NHS Trust

Hammersmith Hospital, London

Shaneel R. Patel

Academic Foundation Trainee in Vascular Surgery

South Thames Foundation School, London

Ivo Pitanguy

The Ivo Pitanguy Clinic and Institute, Rio de Janeiro

Felicity Plaat

Consultant Anaesthetist

Imperial College Healthcare NHS Trust

Hammersmith Hospital, London

Henrique Radwanski

The Ivo Pitanguy Clinic and Institute, Rio de Janeiro

Duke Samson

Department of Neurological Surgery

University of Texas

Southwestern Medical Centre, Dallas, Texas 
Aris Sterodimas

The Ivo Pitanguy Clinic and Institute, Rio de Janeiro

Amanda Venters

Lay Member

Clinical Ethics Committee

Imperial College Healthcare NHS Trust, London

Lay Member

Ethics Committee

British Transplantation Society

Louis Whitworth

Department of Neurological Surgery

University of Texas

Southwestern Medical Centre, Dallas, Texas

Ariel Zosmer

Associate Specialist

Centre for Reproductive Medicine

St. Bartholomew's Hospital, London

Honorary Clinical Senior Lecturer

Centre for Primary Care and Public Health, Blizard Institute

Queen Mary University of London, London 